\title{
Does an increase in water color intensity affect the lake trophic status and phytoplankton metrics?
}

\author{
Tomasz Lenard ${ }^{1, *}$, Wojciech Ejankowski ${ }^{2}$ and Małgorzata Poniewozik ${ }^{3}$ \\ ${ }^{1}$ Departmentof Animal Physiology and Toxicology, Faculty of Biotechnology and Environment Sciences, The John Paul II Catholic \\ University of Lubin, Konstantynów 1i, 20-708 Lublin, Poland \\ ${ }^{2}$ Regional Directorate for Environmental Protection in Lublin, Bazylianówka 46, 20-144 Lublin, Poland \\ 3 Department of Plant Physiology and Biotechnology, Faculty of Biotechnology and Environment Sciences, The John Paul II Catholic \\ University of Lublin, Konstantynów 1i, 20-708 Lublin, Poland
}

\begin{abstract}
During the 11-year period covered by this study (2003-2013), high precipitation events increased the water level in the deep hardwater of Lake Rogóźno (Eastern Poland), causing its water to become browner. We investigated the effect of a change in water color on the physical, chemical, and biological parameters of the lake. The concentration of total phosphorus and nitrogen decreased, whereas the total phytoplankton biomass, coupled with a high biomass of flagellate species, increased, with the increase in water color intensity. Such changes had an effect on the determination of ecological status, based on selected phytoplankton metrics (i.e., Polish, German, and Estonian) as well as the trophic status of Lake Rogóźno. The decrease of phosphorus concentration associated with an increase in water color intensity improved the trophic status of the lake based on Carlson's Trophic State Index. The changes in the phytoplankton community caused the deterioration of the ecological status of the lake when using the Polish and German indices adopted for clear water lakes. The use of the Estonian index, which is adapted to colored lakes, suggested that, despite the increase in water color intensity, the good ecological status of the lake was maintained or even improved. Our findings suggest that, in the event of a transformation like the one that occurred in the lake studied here, the use of only one index, adapted by state environmental monitoring programs in individual European countries, may be insufficient for the appropriate assessment of the ecological status of European lakes.
\end{abstract}

Keywords: phytoplankton metric / Carlson's / Trophic State Index / phytoplankton biomass / climatic condition / water color change

Résumé - Est-ce qu'une augmentation de l'intensité de la couleur de l'eau affecte l'état trophique d'un lac et les paramètres du phytoplancton? Au cours de la période de dix ans couverte par cette étude (2003-2013), les fortes précipitations ont fait monter le niveau d'eau du lac profond à l'eau dure Rogóźno (Pologne orientale), ce qui a rendu l'eau plus brune. Nous avons étudié l'effet d'un changement de couleur de l'eau sur les paramètres physiques, chimiques et biologiques du lac. La concentration de phosphore total et d'azote ont diminué, tandis que la biomasse totale de phytoplancton, associée à une biomasse élevée d'espèces flagellées, a augmenté avec l'augmentation de l'intensité de la couleur de l'eau. De tels changements ont eu un effet sur la détermination de l'état écologique, basé sur certains paramètres du phytoplancton (c.-à-d. polonais, allemand et estonien) ainsi que sur l'état trophique du lac Rogóźno. La diminution de la concentration de phosphore associée à une augmentation de l'intensité de la couleur de l'eau a amélioré l'état trophique du lac selon l'indice de l'état trophique de Carlson. Les changements dans la communauté phytoplanctonique ont causé la détérioration de l'état écologique du lac évaluée par les indices polonais et allemand adoptés pour les lacs d'eau claire. L'utilisation de l'indice estonien, adapté aux lacs colorés, suggère que, malgré l'augmentation de l'intensité de la couleur de l'eau, le bon état écologique du lac a été maintenu ou même amélioré. Nos résultats suggèrent qu'en cas de transformation comme celle qui s'est produite dans le lac étudié ici, l'utilisation d'un seul indice, adapté par les programmes nationaux de

\footnotetext{
*Corresponding author: tomasz.lenard@kul.pl
} 
surveillance environnementale dans les différents pays européens, pourrait être insuffisante pour évaluer adéquatement l'état écologique des lacs européens.

Mots-clés : métrique phytoplancton / indice d'état trophique de Carlson / biomasse phytoplanctonique / conditions climatiques / changement de couleur de l'eau

\section{Introduction}

Water environment, including its physical, chemical, and biological components, is sensitive to any variability in climatic conditions. Nevertheless, the catchment basin, including its area, hydrology, geology, land cover, and land management, plays a key role as a provider of organic and inorganic matter to a lake (Johnes, 1999; Yong and Chen, 2002; Nõges et al., 2003b; Huang et al., 2013). Scenarios of climate change indicate that, in the future, forests and terrestrial biomass will increase in areas receiving sufficient precipitation. Such changes might regulate the flux and fate of $\mathrm{C}, \mathrm{N}, \mathrm{P}$, and Si in catchments; however, the direct detection of these changes would be difficult in terrestrial catchments. Hence, lakes are valuable sentinels for detecting global changes, which in turn might have a major direct and indirect effect on the biota of lakes (Hessen et al., 2009).

One of the most important parameters of climate is precipitation. Climatic variability in precipitation, as a result of global warming or natural climate cycles, greatly influences surface run-off and nonpoint nutrient transport, the hydration of the catchment basin, and the water level of lakes (Vasiljev, 1998; Johnes, 1999; Nõges et al., 2003a; Michalczyk et al., 2011). Furthermore, when the lake catchment area is covered by coniferous or alder forests and peatlands, precipitation can be the main source of humic and fulvic acids supplied to lake waters (Irfanullah, 2009; Klimaszyk et al., 2015; Weyhenmeyer et al., 2016). Thus, lake waters can change their color from blue to brown or can maintain their dystrophic (humic) character (Hongve et al., 2004; Irfanullah and Moss, 2005; Lenard and Ejankowski, 2017). If brownification is an effect of wetter and warmer conditions and/or changes in land use (reduced cultivated area, more coniferous forests, etc.), continued brownification could be expected in coming decades. However, in contrast, if climate change causes reduced precipitation and run-off, lakes might become less colored (Granéli, 2012). In this context, Weyhenmeyer et al. (2016) developed a model of future climate change, in which a homogenous precipitation increase was shown to result in a very heterogeneous increase of water color in Swedish boreal lakes and streams. Permanent or temporal changes in water color may cause variability of habitat conditions, to which phytoplankton can respond very rapidly. Such changes can disrupt not only the time but also the order of occurrence and magnitude of phytoplankton phenological events (Nicolle et al., 2012). Hence, the prediction of changes in phytoplankton communities in lakes is very difficult because many different parameters can affect phytoplankton composition and biomass, especially in an unpredictable world (Lürling and De Senerpont Domis, 2013). Nevertheless, Sepp et al. (2018) recently showed a trend in consecutive changes in water color (water brownification) associated with an increase in organic matter input to European lakes. Such changes can affect the development of primary producers, and thus affect the assessment of lake ecological status in each country belonging to the European Union (EU).

Each member state of the EU is obliged to prepare appropriate metrics to assess the ecological status of surface water. The assessment of lakes should be carried out on those sites in the intercalibration network that are both in the ecoregion and a part of a surface water body type. Biological elements such as phytoplankton, macrophytes, phytobenthos, macroinvertebrates, and fish supported by hydromorphological, chemical, and physicochemical elements are the most important elements in the classification of ecological status of lakes, as proposed in the EU Water Framework Directive (WFD) (EC Parliament and Council, 2000). According to the WFD, phytoplankton metrics should consider species composition, species abundance or biomass, and the intensity of phytoplankton blooms. The WFD defined five normalized numerical boundaries (high, good, moderate, poor, and bad) between the classes of ecological status, which is also called the ecological quality ratio (EQR). The EQR needs to be expressed as a numerical value between zero and one, where values close to zero and one indicate bad and high ecological status, respectively (EC Parliament and Council, 2000).

Chemical and physicochemical variables that support biological elements, which are included in the lakes assessment proposed in the WFD, are the main components of the classification of a lake's trophic status according to Carlson's indices (Carlson, 1977). Three indices were proposed by Carlson (1977): TSI(CHL), TSI(SD), and TSI (TP), based on chlorophyll $a$ concentration, water transparency, and total phosphorus concentration, respectively; a fourth index TSI(TN) based on total nitrogen concentration was proposed by Kratzer and Brezonik (1981), and can also be important in the trophic classification of lakes in the context of water color change. These two approaches, based on selected the WFD's phytoplankton metrics and Carlson's indices for the assessment of lake ecological status or lake trophic status, occasionally yield inconsistent results.

In this study, we intend to answer the following questions: (1) whether the changes in water color intensity affect phytoplankton-based lake assessment and trophic status of a lake; and (2) whether the phytoplankton metrics calibrated for selected European countries are sufficient and appropriate for the evaluation of lake ecological status, in the context of water brownification.

\section{Material and methods}

The study was conducted from 2003 to 2013 in Lake Rogóźno (51 ${ }^{\circ} 22^{\prime} 36^{\prime \prime} \mathrm{N} ; 2^{\circ} 58^{\prime} 21^{\prime \prime}$ E) located in the ŁęcznaWłodawa Lake District (Western Polesie region, East Poland; Kondracki, 2002). The lake is small $\left(0.57 \mathrm{~km}^{2}\right)$, deep (mean depth of $7.4 \mathrm{~m}$, maximum depth of $25.4 \mathrm{~m}$ ), dimictic, and 
devoid of inflow and outflow. The water body was characterized as a mesotrophic, hardwater lake, with extensive stonewort vegetation (Fijałkowski, 1959; Sugier, 2008). The average water level in the lake from 1991 to 2010 was $167.05 \mathrm{~m}$ a.s.1. During 2003-2013, because of high total precipitation, a strong positive trend of increasing water levels in Lake Rogóźno was noted, with an amplitude of $0.6 \mathrm{~m}$ (Michalczyk et al., 2011). Since 2007, the water level has increased, and a large area of the lake catchment (ca. $\left.0.05 \mathrm{~km}^{2}\right)$ has become more hydrated. The relatively large catchment area $\left(7.75 \mathrm{~km}^{2}\right)$ is flat and occupied mostly by arable lands $(38 \%)$, forests $(37 \%)$, and meadows $(11 \%)$. The vegetation in the catchment in the immediate surroundings of the lake is primarily represented by swampy alder forests and coniferous forests with Scots pines.

The water samples were collected monthly (AprilOctober) in 2003, 2005, 2006, 2007, 2010, and 2013; the water hardness was determined in 2003, 2008, and 2013. During stratification (May-September), water samples for analyses were obtained using a Ruttner-type water sampler (2.0 L capacity) from the water surface to the end of the euphotic zone $(0-5 \mathrm{~m})$, which often corresponded to the range of the epilimnion layer, at $1 \mathrm{~m}$ intervals and combined into one collective sample. During the mixing season (April and October), the samples necessary for the calculation of the Polish multimetric index were obtained as detailed above, independent of the extent of the euphotic zone or epilimnion layer. In addition, the Estonian phytoplankton multimetric index was calculated by obtaining two collective water samples at $1 \mathrm{~m}$ intervals during stratification (MaySeptember): the first one was from the metalimnion layer $(6-9 \mathrm{~m})$ and the second from the hypolimnion layer $(12-18 \mathrm{~m})$.

In the laboratory, the samples were analyzed using spectrophotometric methods to determine the concentration of chlorophyll $a$ (Nush, 1980), total phosphorus (TP), total nitrogen (TN), inorganic phosphorus $\left(\mathrm{P}-\mathrm{PO}_{4}\right)$, and nitrogen $\left(\mathrm{DIN}=\mathrm{N}-\mathrm{NO}_{x}+\mathrm{N}-\mathrm{NH}_{4}\right.$; Hermanowicz et al., 1999). The water color was measured colorimetrically at $440 \mathrm{~nm}$ (converted to $\mathrm{mg} \mathrm{Pt} \mathrm{L}^{-1}$; Lean, 1998); the water hardness was determined using the titrimetric method by using disodium EDTA in mval $\mathrm{L}^{-1}$ and converting to $\mathrm{mg} \mathrm{CaCO}_{3} \mathrm{~L}^{-1}$ (Hermanowicz et al., 1999). Other physical and chemical parameters such as water temperature, electrolytic conductivity (EC), $\mathrm{pH}$ values, and transparency by Secchi disk visibility (SD) were measured in situ. The water temperature was used to determine the length of the mixing period.

The samples for phytoplankton analysis were fixed with Lugol's iodine solution and a formalin glycerine mixture (proportion 3:1). The abundance of phytoplankton was determined according to standard methods (Utermöhl, 1958) and the algal biovolume was calculated using a formula described by Hillebrand et al. (1999). For more details regarding phytoplankton determination, please see Lenard and Ejankowski (2017).

The chemical and biological data were used to evaluate the trophic status of the lake using the following trophic state indices: TSI(CHL), TSI(SD), TSI(TP), and TSI(TN), which were calculated using the equations described by Carlson (1977) and Kratzer and Brezonik (1981).

In order to assess the ecological status of the lake, we used the multimetric phytoplankton index for Polish lakes (PMPL;
Hutorowicz and Pasztaleniec, 2014). Nevertheless, to verify accuracy of the PMPL following changes in water color in Lake Rogóźno, we also adopted two other multimetric indices proposed for phytoplankton-based lake assessment in Germany (Phyto-See-Index, PSI; Mischke et al., 2008) and Estonia (Nygaard, 1949; Ott and Laugaste, 1996; Ott et al., 2005).

The Polish phytoplankton assessment system for lakes is based on a combination of typological criteria from the WFD and is supplemented by one additional factor-Schindler's ratio (Schindler, 1971), the value of which below 2 allows distinguishing lakes with naturally lower trophy than those naturally exposed to eutrophication; for more details, please see Kolada et al., (2005) and the latest verification (Kolada et al., 2017). According to the PMPL method (Hutorowicz and Pasztaleniec, 2014), the samples for analyses were obtained from the deepest part of the lake from the epilimnion or euphotic zone, four times during the growing season in the following distribution: one sample representing spring (March-May), two samples representing summer (JuneSeptember), and one sample representing autumn (October). The final PMPL index values range from 0 to 5 and can be transformed to a normalized EQR that ranges from 0 (the worst status) to 1 (the best status); for more details, please see Hutorowicz and Pasztaleniec (2014).

The German phytoplankton assessment system for lakes is based on a combination of typological criteria from the WFD and the lake types proposed by LAWA (Mathes et al., 2002). For the assessment, the samples for analyses were obtained from the deepest part of the lake from the epilimnion or euphotic zone, six times per year (May-September), in the following distribution: one sample was taken in May, June, August, and September; two samples were taken in July. The final PSI index values range from 0 to 5 and can be transformed to EQR; for more details, please see Mischke et al. (2008). We adopted this metric in our investigation, because it takes into consideration the list of indicator taxa, with their trophic scores, as well as weighting factors that can be important in the case of phytoplankton community change as a result of water browning.

The Estonian phytoplankton assessment system for lakes is based on a combination of typological criteria from the WFD as well as natural parameters, such as the content of organic compounds (humic substances) that can affect light conditions in the water column and adsorb phosphates (Ott et al., 2005). Furthermore, this multimetric index emphasises information about mutual relationships between phytoplankton groups and phytoplankton richness. For the assessment, the samples for analyses were obtained during stratification from two to three thermal layers of the lake (epilimnion, metalimnion, and hypolimnion) four times per year (May, July, August, and September). The final metric values range from 0 to 5; however, the national $\mathrm{EQR}$ values are discontinuous and defined as $H / G=0.8$ (high/good status); $G / M=0.6$ (good/ moderate status); $M / P=0.4$ (moderate/poor status); and $P / B=0.2$ (poor/bad status). For more details, please see Ott et al. (2005) and Phillips et al. (2014).

The total precipitation and mean air temperatures in the study area were calculated according to data from a meteorological station in the town of Włodawa (Polesie region), as well as from an online service (www.tutiempo.net). 


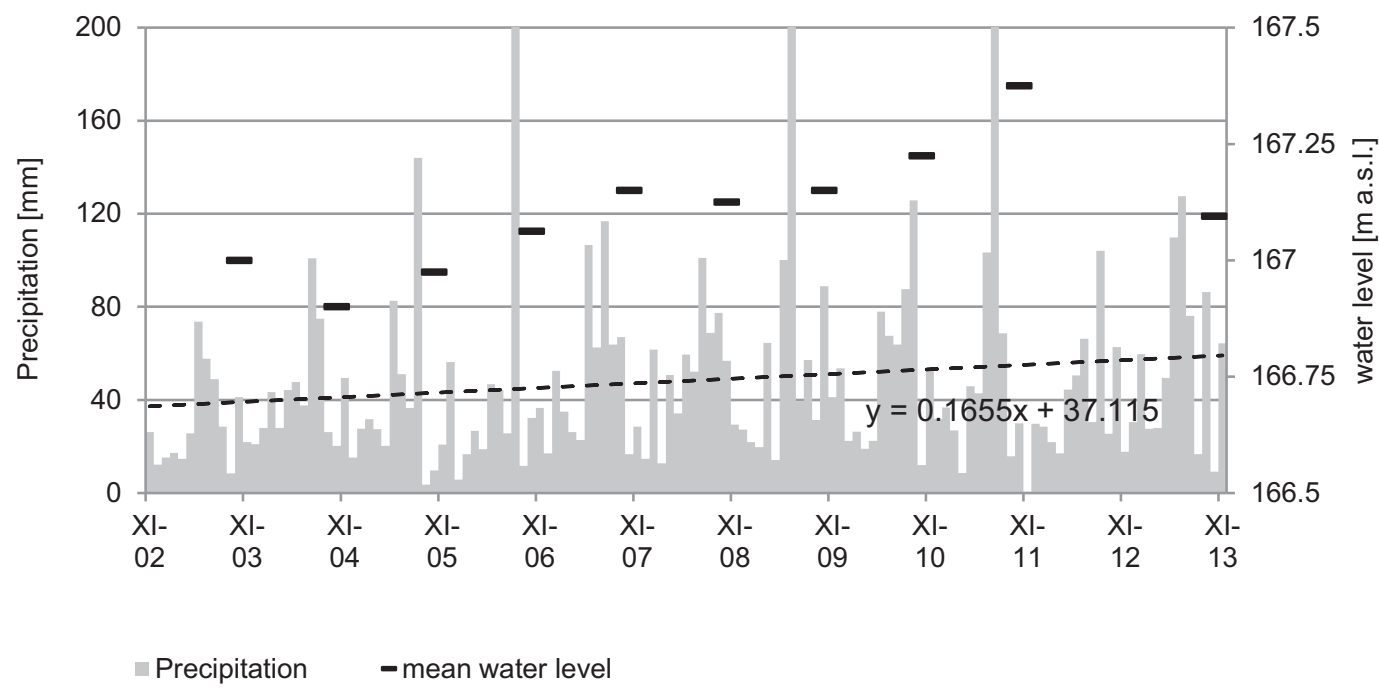

Fig. 1. The mean values of water level and monthly precipitation totals in Lake Rogóźno during 2003-2013. Explanations: the dashed line represents precipitation trend.

All biological and physicochemical parameters of the water, as well as selected multimetric and trophic state indices, were investigated at two different periods with respect to humidity: the dry (2003-2006, DP) and wet (2007-2013, WP) periods.

Nonparametric tests were used if the data did not meet the assumptions of parametric methods. The normality of data was tested using the Lilleforst test, and the homogeneity of variance was analyzed using the Levene test. The MannWhitney test was used to verify the differences in physical, chemical, and biological parameters between the periods, DP and WP. The calculations were performed according to Sokal and Rohlf (1995) by using PSPP ver. 0.9.0. The relationship between phytoplankton biomass and chlorophyll $a$ concentration was assessed using the Spearman rank correlation test. The data were logarithmically transformed before the calculations.

\section{Results}

During the 11-year period covered by the study (2003-2013), a long period of wet weather increased the water level in Lake Rogóźno (Fig. 1). This precipitation event allowed us to distinguish two different periods: the dry period (DP, 2003-2006) and the wet period (WP, 2007-2013). The annual average precipitation differed considerably between the periods and was 480.2 and $629.9 \mathrm{~mm}$ for the DP and WP, respectively. The changes in precipitation had an effect on water level fluctuation in Lake Rogóźno, of which the amplitude was around $0.6 \mathrm{~m}$ during the 11-year study period (Fig. 1).

The fluctuation in water level had a profound effect on the physicochemical and biological parameters of the water in Lake Rogóźno (Tab. 1). The most important change between the DP and WP was the water color, for which values more than doubled between the periods, whereas the values of EC decreased considerably. Such large changes in water color did not affect the water hardness in Lake Rogóźno, which ranged from $98.5 \mathrm{mg} \mathrm{CaCO}_{3} \mathrm{~L}^{-1}$ in 2003 (DP) to $101.5-109.5 \mathrm{mg}$ $\mathrm{CaCO}_{3} \mathrm{~L}^{-1}$ in 2008 , and from 140 to $152 \mathrm{mg} \mathrm{CaCO}_{3} \mathrm{~L}^{-1}$ in 2013 (WP). Statistically, significant differences were also noted for total phosphorus and nitrogen concentration, which were considerably lower in the WP. The direction of the change in TN and TP values had direct effect on the ratio of TN:TP, which significantly changed between the periods. Other physicochemical parameters, i.e., the $\mathrm{pH}$ of water and water transparency (SD), did not show significant differences between the DP and WP (Tab. 1). The changes in physicochemical parameters were coupled with variation in biological parameters, for which the values were considerably higher in the WP. The total phytoplankton biomass was more than three times higher, the flagellate:nonflagellate ratio was more than five times higher, and the biomass of flagellates was more than eight times higher in the WP than in DP (Tab. 1). Hence, changes in water level coupled with water brownification (change in water color) strongly stimulated the development of phytoplankton species, especially flagellated ones (Fig. 2). In the WP, the phytoplankton biomass was dominated by species such as Cryptomonas curvata O.V. Troitsk., C. marssonii Skuja, Plagioselmis nannoplanctica (Skuja) G. Novarino, I.A.N. Lucas \& Morrall, and Ceratium hirundinella (O.F. Müll.) Dujard (flagellate species) and, to a lesser extent, by Aphanizomenon gracile (Lemmermann) Lemmermann, Coenococcus planctonicus Korshikov, and Closterium acutum var. variabile (Lemmermann) Willi Kreiger (nonflagellate species). During the DP (period with low water color), filamentous nonflagellate species, i.e., Planktothrix rubescens (De Candolle ex Gomont) Anagnostidis \& Komárek, P. agardhii (Gomont) Anagnostidis \& Komárek, and Limnothrix planctonica (Woloszynska) Meffert, or coccal blue-green algae, i.e., Anathece clathrata (W. West \& G.S. West) Komárek, Kastovsky \& Jezberová, Snowella lacustris (Chodat) Komárek \& Hindák, and Radiocystis geminata Skuja, dominated, whereas the presence of flagellate species was negligible (Fig. 2). Nevertheless, the remarkable changes in phytoplankton composition and biomass during 
T. Lenard et al.: Knowl. Manag. Aquat. Ecosyst. 2018, 419, 46

Table 1. The mean values and standard deviations of the physico-chemical and biological parameters in the euphotic layer (0-5 m) of Lake Rogóźno in the dry (DP, 2003-2006) and wet (WP, 2007-2013) periods compared using a Mann-Whitney test (Z).

\begin{tabular}{|c|c|c|c|c|}
\hline Parameter & DP & WP & $\mathrm{N}$ & $\mathrm{Z}$ \\
\hline $\mathrm{TN}\left[\mathrm{mg} \mathrm{L}^{-1}\right]$ & $2.78(0.84)$ & $2.24(0.69)$ & 42 & $2.13^{*}$ \\
\hline $\mathrm{DIN}\left[\mathrm{mg} \mathrm{L}^{-1}\right]$ & $0.69(0.29)$ & $0.75(0.52)$ & 42 & 0.23 \\
\hline DIN:TN & $0.26(0.14)$ & $0.31(0.24)$ & 42 & -0.31 \\
\hline $\mathrm{TP}\left[\mathrm{mg} \mathrm{L}^{-1}\right]$ & $0.17(0.13)$ & $0.07(0.05)$ & 42 & $2.14^{*}$ \\
\hline $\mathrm{P}_{-} \mathrm{PO}_{4}\left[\mathrm{mg} \mathrm{L}^{-1}\right]$ & $0.02(0.01)$ & $0.02(0.02)$ & 42 & 0.04 \\
\hline TN:TP & $46(69.4)$ & $51.6(32.2)$ & 42 & $-1.97^{*}$ \\
\hline $\mathrm{pH}$ & $8.29(0.37)$ & $8.25(0.57)$ & 42 & 0.12 \\
\hline $\mathrm{EC}\left[\mu \mathrm{S} \mathrm{cm} \mathrm{c}^{-1}\right]$ & $369.3(72.4)$ & $245.3(17.24)$ & 42 & $5.54^{* * *}$ \\
\hline Colour [mg Pt L ${ }^{-1}$ ] & $12.18(9.9)$ & $30.53(21.4)$ & 42 & $-2.69^{*}$ \\
\hline $\mathrm{SD}[\mathrm{m}]$ & $2.84(1.08)$ & $2.66(0.76)$ & 42 & 0.39 \\
\hline Chlorophyll $a\left[\mu \mathrm{g} \mathrm{L}^{-1}\right]$ & $9.06(4.61)$ & $10.87(8.93)$ & 42 & -0.47 \\
\hline Total biomass of phytoplankton $\left[\mathrm{mg} \mathrm{L}^{-1}\right]$ & $2.32(2.11)$ & $8.47(8.26)$ & 42 & $-4.36^{* * *}$ \\
\hline Biomass of flagellates $\left[\mathrm{mg} \mathrm{L}^{-1}\right]$ & $0.62(0.49)$ & $5.25(8.02)$ & 42 & $-4.89^{* * *}$ \\
\hline Biomass of non-flagellates $\left[\mathrm{mg} \mathrm{L}^{-1}\right.$ ] & $1.70(1.81)$ & $3.2(2.53)$ & 42 & $-2.70^{* *}$ \\
\hline Flagellates:Non-flagellates & $0.54(0.60)$ & $2.78(4.92)$ & 42 & $-2.50^{*}$ \\
\hline
\end{tabular}

Statistically significant at: ${ }^{*} p<0.05,{ }^{* *} p<0.01,{ }^{* * *} p<0.001$

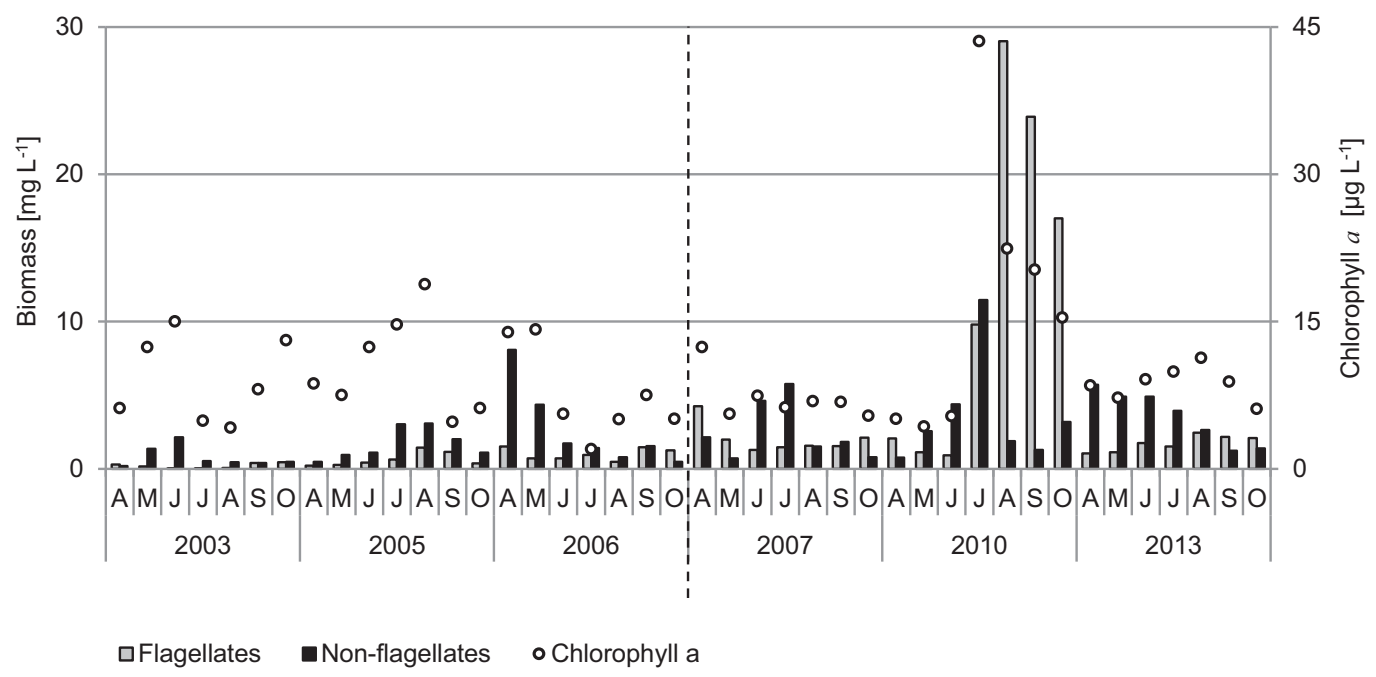

Fig. 2. Temporal variations of phytoplankton biomass and chlorophyll a concentration in Lake Rogóźno during 2003-2013. Explanations: the dashed line separates the dry (DP) and wet (WP) periods.

2003-2013 weakly corresponded to the values of chlorophyll $a$ concentration (Fig. 2), which were not significantly different between the DP and WP (Tab. 1).

The differences in water level had some effect on the trophic status of the lake. According to the mean values of trophic state indices (TSIs), Lake Rogóźno should be categorized as a moderate eutrophic lake (Tab. 2); however, large discrepancies of TSIs were noted during the study (Fig. 3a). The highest changes in TSI values between the DP and WP were noted among the parameters based on nutrient concentrations, TSI(TP) and TSI(TN). The values of both parameters ranged from 62 to 88 in the DP, indicating a high trophic status (high eutrophy/hypertrophy); however, in the WP, their values were considerably lower and ranged from 49 to 72, placing Lake Rogóźno in a class of moderate eutrophy (Fig. 3a). Hence, a significant increasing trend in TSI(TN)-TSI
(TP) deviation was noted during 2003-2013, indicating a transition from nitrogen limitation in the DP (2003-2006) to secondary phosphorus limitation in the WP (2007-2013, Fig. 3b). This was also confirmed by the decline in the mean values of TSI(TP) between the DP and WP (Tab. 2). The change in total phosphorus concentration coincided with the change in the mean values of the TN:TP ratio, which were significantly higher during the WP (Tab. 1). Nevertheless, considering the multiple deviations of TSI(CHL) from TSI (TN) or TSI(TP) and TSI(SD), some new information about limiting factors was obtained. In the DP, a low biomass of phytoplankton was noted (Fig. 2), which did not correspond to chlorophyll a concentration (Spearman test, $r=0.41$, $p>0.05$ ). Hence, the multiple deviations also indicated that factors other than nutrients, such as zooplankton grazing, could limit phytoplankton growth during the DP (Fig. 3c). In 
Table 2. Differences in the average values (with standard deviations) of the trophy state indices (TSI), selected phytoplankton metrics (Polish, PMPL; German, PSI; and Estonian), and species diversity (Shannon-Wiener index, Pielou evenness index, and species richness) in Lake Rogóźno between the dry (DP, 2003-2006) and wet (WP, 2007-2013) periods.

\begin{tabular}{lll}
\hline Parameter & DP & WP \\
\hline TSI (CHL) & $51(6.08)$ & $51(6.43)$ \\
TSI (SD) & $46(5.95)$ & $47(4.21)$ \\
TSI (TN) & $68(3.98)$ & $65(4.67)$ \\
TSI (TP) & $72(14.28)$ & $62(9.92)$ \\
PMPL & $0.70(0.20)$ & $0.43(0.21)$ \\
PSI & $0.62(0.08)$ & $0.47(0.17)$ \\
Estonian index & $0.6(0.11)$ & $0.6(0.05)$ \\
Shannon-Wiener Index & $1.86(0.50)$ & $2.04(0.55)$ \\
Pielou's Eveness Index & $0.63(0.15)$ & $0.58(0.15)$ \\
Species richness & $19.4(5.29)$ & $34.2(7.97)$ \\
\hline
\end{tabular}

contrast, high phytoplankton biomass in the WP corresponded to chlorophyll $a$ values (Spearman test, $r=0.74, p<0.001$; Fig. 2). The multiple deviations of TSIs (Fig. 3c) suggest that phytoplankton growth in the WP was limited by zooplankton grazing, as it was in the DP. However, some deviant points indicated that a community of large algae in the WP was also limited by phosphorus concentration and, to some extent, by light (an increase in water color influenced water transparency).

The changes in water color in Lake Rogóźno affected phytoplankton species diversity (Tab. 2). The mean number of species during the WP was almost two-fold higher than in the DP. Similarly, the Shannon-Wiener index was higher in the WP; however, the evenness index was similar in both periods (Tab. 2). We used three metrics based on the phytoplankton community - Polish (PMPL), German (PSI), and Estonian to assess the ecological status of Lake Rogóźno (Tab. 2). The PMPL and PSI metrics indicated generally good ecological status in the DP and a severe deterioration to moderate status in the WP. In contrast, the Estonian index indicated good ecological status in both periods, showing even better values in the WP (Tab. 2). The values of the PMPL and PSI metrics in particular years were highly differentiated and ranged from high (in the DP) to even bad ecological status in the WP (Fig. 4). Only the values of the Estonian index were always within the range of good or even high ecological status; however, in 2006 , the values were close to a moderate status because of metalimnetic bloom of filamentous cyanobacteria, $P$. rubescens that strongly influenced the calculation of the index.

\section{Discussion}

Studies conducted in 2003-2013 in Lake Rogóźno showed a significant increase of precipitation and, in turn, a secondary increase of water level in the lake, which caused large discrepancies in the values of physicochemical (water color, electrolytic conductivity, and nutrient concentrations) as well as biological parameters (phytoplankton biomass and chlorophyll $a$ concentration). Therefore, we assessed the changes in trophic characteristics of the lake using Carlson Trophic State
Indices, and also assessed lake ecological status by using selected phytoplankton metrics, i.e., Polish, German, and Estonian, and determined that there are large differences in the assessment between the dry (DP) and wet (WP) periods.

The variability of precipitation during 2003-2013 generally affected water color and electrolytic conductivity in Lake Rogóźno. High precipitation in the WP (2007-2013) caused increases in runoff from the catchment basin, which is occupied mostly by swampy alder forests and coniferous forests with Scots pines (the main source of humic substances), arable lands, and meadows. The role of coniferous forests as the source of a high concentration of dissolved organic carbon in lakes was indicated by Irfanullah and Moss (2005). Pace and Cole (2002) positively correlated changes in water color to changes in dissolved organic carbon, which consists of humic and fulvic acids with relatively high apparent molecular weight (Leenheer and Croué, 2003). Water brownification caused significant changes in other physicochemical parameters, e.g., a decrease of total nitrogen and phosphorus concentration in Lake Rogóźno in the WP. Humic acids can form complexes with metals such as magnesium and calcium, as well as with nonmetals such as phosphorus, in the water, which can reduce their total amount in the aquatic environment (Pagenkopf and Whitworth, 1981; de Haan and de Boer, 1986). Conversely, colloidal complexes of humic acids and inorganic phosphorus can be a source of bioavailable phosphorus during its depletion in water (de Haan et al., 1990; Jansson, 1998). In addition, Hessen et al. (2009) suggested that, under some circumstances, higher precipitation can also have a dilution effect on the concentration of organic nitrogen associated with dissolved organic matter in lakes. Hence, the ratios of total nitrogen to other elements might depend on the relative contribution of organic versus inorganic nitrogen, which might again depend on catchment properties (Hessen et al., 2009). However, in Lake Rogóźno, the dilution effect seemed to be negligible because, regardless of brownification, the $\mathrm{pH}$ of water was generally similar in both periods (DP and WP).

The changes in nitrogen and phosphorus concentrations in the lake affected the values of Carlson's TSI indices, TSI(TN) and TSI(TP), indicating a strong transition from nitrogen limitation in the DP to phosphorus limitation in the WP, along the deviation of TSI(TN)-TSI(TP). Large discrepancies of phosphorus concentration in lakes depend on the export of diffuse pollution from the catchment area (Szyper and Gołdyn, 2002) or internal phosphorus loading from the lake sediments after a reduction of external loading (Søndergaard et al., 1999). In Lake Rogóźno, the resuspension of sediments seems to be negligible because the lake is deep and dimictic and shows strong stratification in summer. Hence, the trend of increasing water browning mainly affected phosphorus depletion in the water and its availability for the phytoplankton community. Therefore, significant decrease in TSI(TP) values in the WP might indicate an improvement of the trophic status of the lake during the process of water browning. These changes also caused the transformation of the phytoplankton community between the DP and WP. During the WP, with high water color, the phytoplankton community was mainly dominated by small mixotrophic flagellate species from Plagioselmis and Cryptomonas or large flagellates from Ceratium. Motile or buoyant species may regulate their vertical position in the water column and maximize its photosynthetic efficiency, hence their 

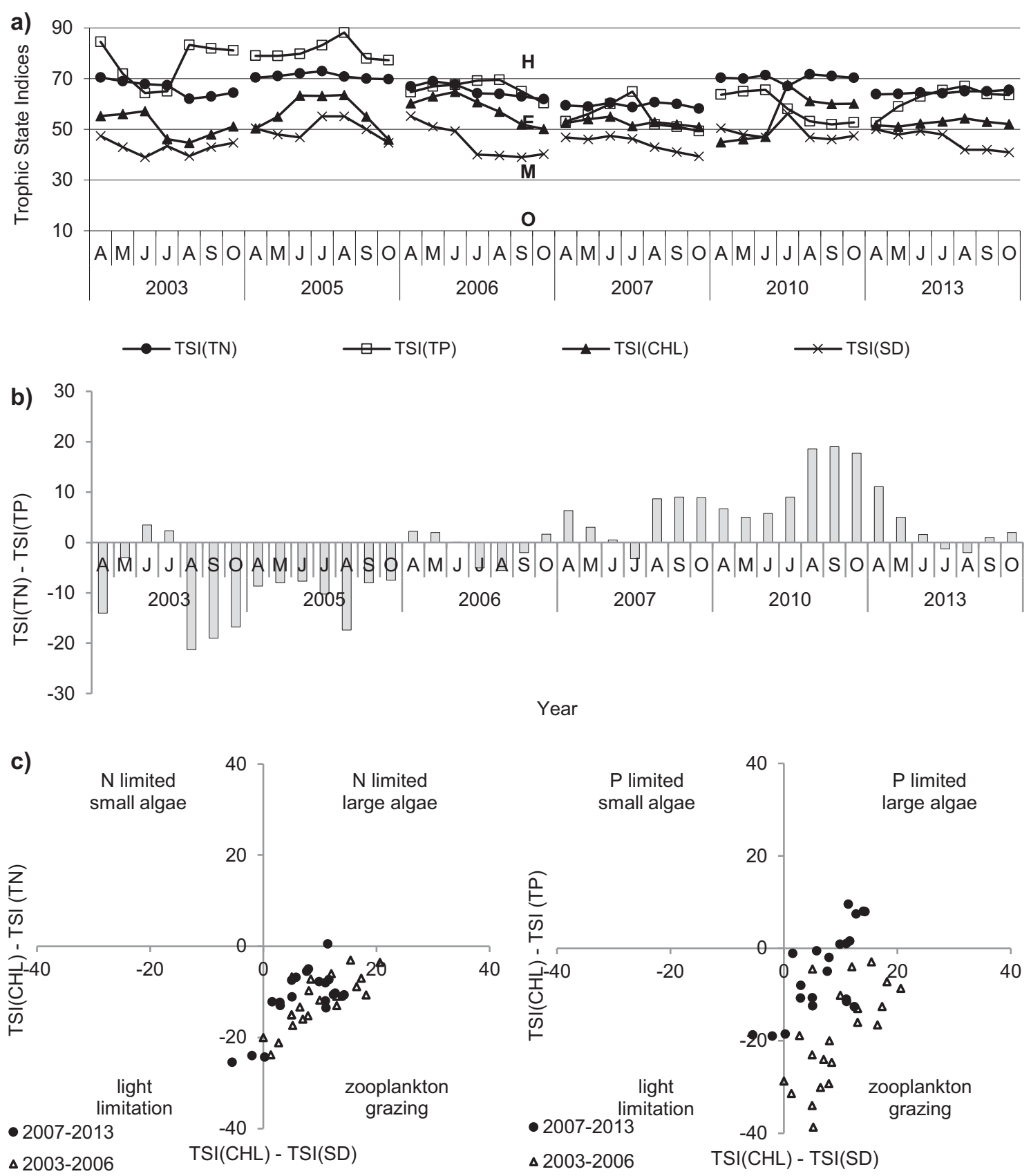

Fig. 3. Dynamics of the trophic state indices in the dry (2003-2006) and wet (2007-2013) periods: (a) general differences between TSI indices; abbreviations: H, hypertrophy; E, eutrophy; M, mesotrophy; O, oligotrophy; (b) deviations of TSI(TN) and TSI(TP); (c) diagrams of multiple deviations of TSI(CHL) from TSI(TN), TSI(TP), and TSI(SD).

development might be favored in colored lakes with poor light penetration (Jones, 1998). Moreover, a high density of mixotrophic algae in the WP during phosphorus limitation could be a reason of grazing on bacteria rich in phosphorus, which can develop in great numbers in colored lakes (Jansson et al., 1996; Pålsson and Granéli 2004). Conversely, during nitrogen limitation in the DP, the lake was dominated by bluegreen algae: filamentous species belonging to Planktothrix and Limnothrix, or colonial species belonging to Anathece and Snowella. Further, the values of TSI(CHL) and TSI(SD), which are based on the concentration of chlorophyll $a$ and water transparency, respectively, indicated that Lake Rogóźno should be classified as mesoeutrophic, independent of the water browning. However, new information about limiting factors was obtained according to the multiple deviations of the TSIs (based on nutrients, water transparency, and chlorophyll a), which indicated zooplankton grazing as a limiting factor (except nitrogen) for phytoplankton development during the DP. The limiting role of zooplankton grazing in Lake Rogóźno was possible because, in the DP, the phytoplankton community was dominated by large, less edible, nonflagellates mainly belonging to cyanobacteria, whereas the abundance of smaller species, which are relatively more susceptible to predation, was negligible. In the WP, some outlier points confirmed that the 


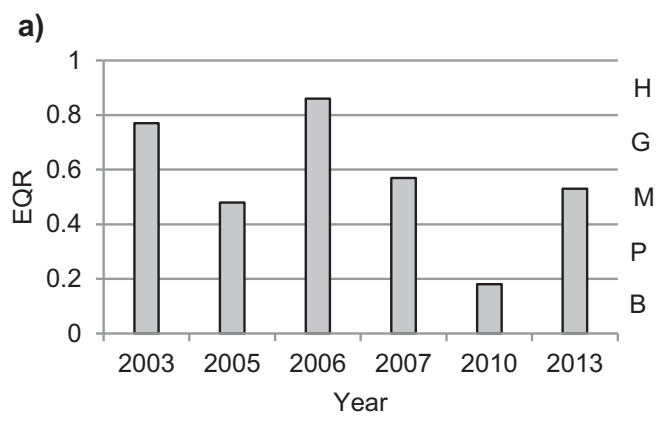

b)

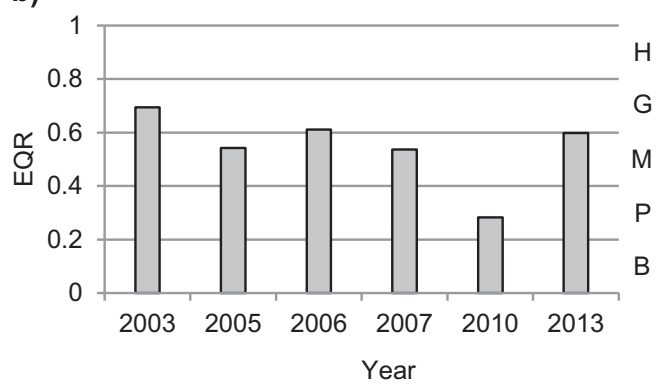

c)

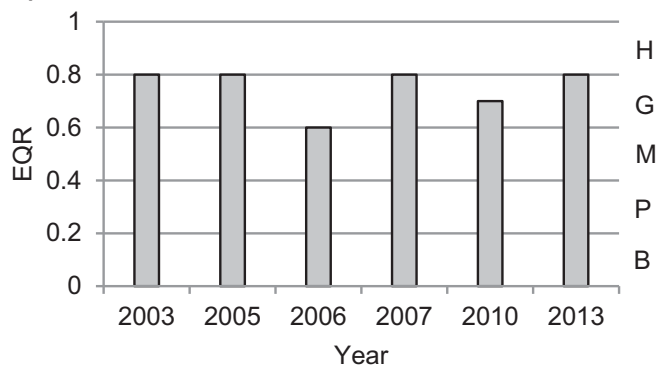

Fig. 4. Index values and status classes indicating the ecological quality ratio (EQR) of Lake Rogóźno during 2003-2013 according to selected phytoplankton metrics: (a) Polish (PMPL), (b) German (PSI), and (c) Estonian. Abbreviations: H, high; G, good; M, moderate; P, poor; B, bad ecological status.

phytoplankton community was limited by phosphorus; however, other points also indicated the role of zooplankton grazing or light limitation. This shows the complexity of factors affecting the phytoplankton community during a significant transformation of the aquatic environment under the influence of the ongoing process of water color changes in Lake Rogóźno. Nevertheless, the increase of water color due to high precipitation positively affected biodiversity, as well as the number of species present during the WP. Such changes also corresponded with a considerably greater phytoplankton biomass, especially the biomass of flagellates, in the WP than in the DP. This is consistent with the results of Nürnberg and Shaw (1999), who stated that primary productivity can be considerably higher in colored lakes than in clear water lakes. The role of natural geo-climatic descriptors, such as precipitation and temperature, that largely drive freshwater biodiversity on a European scale, has been indicated by Feld et al. (2016).

The appropriate assessment of the ecological status of Lake Rogóźno in the context of increasing water color is difficult. Inconsistent results were obtained when comparing results from three approaches to ecological status assessment based on phytoplankton, i.e., the Polish, German, and Estonian. The two phytoplankton metrics, the Polish (PMPL) and German (PSI), indicated the deterioration of the ecological status of the lake from high, good, or slightly moderate ecological status in the DP to moderate, poor, or even bad ecological status in the WP. Both metrics are based on phytoplankton biomass and the concentration of chlorophyll a (Mischke et al., 2008; Hutorowicz and Pasztaleniec, 2014). Hence, significant differences in the phytoplankton biomass and high disproportion of flagellates between the DP and WP were the main factors affecting the deterioration of the ecological status of Lake Rogóźno in the WP according to PMPL and PSI metrics. The Polish metrics (PMPL) emphasized three mandatory metrics: "chlorophyll $a$," "total biomass," and "biomass of cyanobacteria"; however, these are not appropriate for colored lakes. Thus, the large share of flagellates in the phytoplankton community of Lake Rogóźno during the WP was only validated in the mandatory metrics, i.e., "total biomass" or "chlorophyll a." The last review of the typology of Polish lakes (Kolada et al., 2017) still includes Schindler's ratio (Schindler, 1971), and the effect of the relative area of the lake and its catchment to the volume of the lake is a remarkable typological tool for determining reference conditions for phytoplankton. According to the statistical analysis performed by Kolada et al. (2005), a Schindler's ratio below 2 allows distinguishing lakes with naturally lower trophy than those naturally exposed to eutrophication. Schindler's ratio in Lake Rogóźno was 1.92, indicating that the lake should have a low trophic state, which is inconsistent with the values of Carlson's indices from 2003 to 2013. This approach includes the role of the catchment area, but does not consider the type of catchment as a source of colored substances delivered to the lake. In general, for the typology of Polish lakes, this approach is sufficient; however, in the context of increasing water color of many European lakes (Sepp et al., 2018), it seems to be insufficient for appropriately determining the ecological status of a lake such as Lake Rogóźno. Similarly, the assessment of the ecological status of Lake Rogóźno based on the German index (PSI) seems to be insufficient. We adopted these metrics in our investigation, because they consider the list of indicator taxa (PTSI metric) along with their trophic scores and weighting factors (Mischke et al., 2008), which can be important in the case of phytoplankton community changes due to water browning. According to the lake types included in the LAWA proposal (Mathes et al., 2002), Lake Rogóźno should be characterized as a lowland lake with phytoplanktonbased lake type 13 and a ratio of lake volume to catchment area below 1.5. Nevertheless, the PTSI list of indicator taxa for lake type 13 does not include flagellate species as indicator species, but these dominated the phytoplankton biomass of Lake Rogóźno during the WP (i.e., C. curvata, C. marssonii, $P$. nannoplanctica, and C. hirundinella). Hence, such species were excluded from the calculation of the PTSI metric, and this probably affected the final calculation of the PSI index in the WP. Therefore, both metrics (Polish and German) had similar values during the 11-year period of study; however, they should not be used when monitoring lakes with transformations such as those found in Lake Rogóźno.

The Estonian index yielded different results in the assessment of ecological status of Lake Rogóźno. According to the Estonian typology implemented for colored lakes (Ott et al., 2005), the lake studied here was classified as a light-colored 
hardwater lake. In both the periods, the DP and WP, the values of the Estonian index never fell below the boundary of good ecological status. Furthermore, the ecological status of Lake Rogóźno was even better after the increase in water color (in the WP). The main difference between the Estonian and Polish or German metrics is that the former emphasized phytoplankton diversity and species richness. Hence, modified Pielou's index J (Pielou, 1966), "Nygaard's modified compound quotient" (PCQ; Nygaard, 1949; Ott and Laugaste, 1996), and "description of the community (PPS)" are, other than chlorophyll $a$, the main components of the index. Furthermore, the Nygaard's modified compound quotient includes the biomass of flagellate species belonging to Cryptophyceae or Dinophyceae, which were among the dominant phytoplankton groups in Lake Rogóźno during the WP. Moreover, unlike other metrics calculated in the European Union (Phillips et al., 2014; Pasztaleniec, 2016), the samples used for the calculation of the Estonian index consider thermal stratification from two to three thermal layers of the lake (epilimnion, metalimnion, and hypolimnion). Hence, higher values (on the boundary of a good ecological status) of the Estonian index were obtained in the DP (in 2006) because of the bloom of filamentous cyanobacteria $P$. rubescens in the metalimnion layer of Lake Rogóźno (Lenard, 2009). Nevertheless, considering the natural conditions of this lake, i.e., morphometric characteristics and catchment properties, the approach proposed in the Estonian index seems to be the best fitted to determine the appropriate ecological status of Lake Rogóźno. Nonetheless, the Estonian index is often not treated as a useful metric in monitoring programs (Pasztaleniec, 2016). However, the example of Lake Rogóźno showed that changes in water color stimulated further changes in the physicochemical properties of water and caused a shift in the phytoplankton community during the 11 years of the study (Lenard and Ejankowski, 2017). Therefore, a phytoplankton index that considers phytoplankton diversity and species richness, such as the Estonian index, should be useful in lake monitoring programs, particularly in conditions of transformations like those occurred in Lake Rogóźno.

\section{Conclusions}

- The increase in water color intensity was linked to the decrease in nutrient concentrations in water, which improved the trophic status of the lake, as expressed by Carlson's Trophic State Indices, e.g., TSI(TP) and TSI (TN).

- The increase in water color caused the deterioration of the ecological status of Lake Rogóźno based on the PMPL index adopted in Poland, as well as on the German (PSI) index.

- The increase in water color did not affect the ecological status of Lake Rogóźno based on the Estonian index adopted for colored lakes; in contrast, the inclusion of species composition, species diversity, and species richness in the calculation of the index suggested that the increase in water color might even improve the ecological status of Lake Rogóźno. This is consistent with the improvement of trophic status of the lake during the ongoing process of water brownification, as based on Carlson's indices, e.g., TSI(TP) and TSI(TN).

\section{References}

Carlson RE. 1977. A trophic state index for lakes. Limnol Oceanogr 22: 361-369.

de Haan HR, de Boer T. 1986. Geochemical aspects of aqueous iron, phosphorus and dissolved organic carbon in the humic Lake Tjeukemeer, The Netherlands. Freshw Biol 16: 661-672.

de Haan HR, Jones RI, Salonen K. 1990. Abiotic transformations of iron and phosphates in humic lake water, revealed by double isotope labelling and gel filtration. Limnol Oceanogr 35: 491-497.

EC, Parliament and Council 2000. Directive of the European Parliament and of the Council 2000/60/EC.

Feld ChK, Birk S, Eme D, Gerisch M, Hering D, Kernan M, Mailehte K, Mischkef U, Otte I, Pletterbauerg F, Poikaneh S, Salgadod J, Sayerd CD, van Wicheleni J, Malard F. 2016. Disentangling the effects of land use and geo-climatic factors on diversity in European freshwater ecosystems. Ecol Indic 60: 71-83.

Fijałkowski D. 1959. Plant associations of lakes situated between Łęczna and Włodawa and of peat-bogs adjacent to these lakes. Annales UMCS Sectio B 14: 131-204.

Granéli W. 2012. Brownification of Lakes. In: Bengtsson L, Herschy R, Fairbridge R, eds. Encyclopedia of Lakes and Resevoirs, Berlin: Springer, pp. 117-119.

Hermanowicz W, Dojlido J, Dożańska W, Koziorowski B, Zerbe J. 1999. Fizyczno-chemiczne badanie wody i s cieków, Wyd. Arkady, Warszawa, $556 \mathrm{p}$.

Hessen DO, Andersen T, Larsen S, Skjelkvåle BL, de Wit HA. 2009. Nitrogen deposition, catchment productivity, and climate as determinants of lake stoichiometry. Limnol Oceanogr 54: 2520-2528.

Hillebrand H, Dürselen CD, Kirschtel D, Pollingher U, Zohary T. 1999. Biovolume calculation for pelagic and benthic microalgae. J Phycol 35: 403-424.

Hongve DG, Riise G, Kristiansen JF. 2004. Increased colour and organic acid concentrations in Norwegian forest lakes and drinking water: a result of increased precipitation? Aquat Sci 66: 231-238.

Huang J, Zhan J, Yan H, Wu F, Deng X. 2013. Evaluation of the impacts of land use on water quality: A case study in the Chaohu Lake Basin. Sci World J 2013: 329187.

Hutorowicz A, Pasztaleniec A. 2014. Phytoplankton metric of ecological status assessment for Polish lakes and its performance along nutrient gradients. Pol J Ecol 62: 525-542.

Irfanullah HM. 2009. On the role of forested catchment in acid lake limnology. Turk J Fish Aquat Sci 9: 227-230.

Irfanullah HM, Moss B. 2005. Comparative limnology of waters in a coniferous forest: is a generalisation possible? Freshw Forum 24: 59-81.

Jansson M, Blomqvist P, Jonsson A, Bergstöm AK. 1996. Nutrient limitation of bacterioplankton, autotrophic and mixotrophic phytoplankton, and heterotrophic nanoflagellates in Lake Örträsket. Limnol Oceanogr 41: 1552-1559.

Jansson M. 1998. Nutrient limitation and bacteria: phytoplankton interactions in humic lakes. In: Hessen DO, Tranvik LJ, eds. Aquatic Humic Substances, Ecological Studies 133, Berlin: Springer, pp. 177-195.

Johnes PJ. 1999. Understanding lake and catchment history as a tool for integrated lake management. In: Harper DM, Brierley B, Ferguson AJD, Phillips G, eds. The ecological bases for lake and reservoir management. Hydrobiologia 395/396: 41-60.

Jones RI. 1998. Phytoplankton, primary production and nutrient cycling. In: Hessen DO, Tranvik LJ, eds. Aquatic Humic Substances, Ecological Studies 133, Berlin: Springer, pp. 145-176. 
Klimaszyk P, Rzymski P, Piotrowicz R, Joniak T. 2015. Contribution of surface runoff from forested areas to the chemistry of a throughflow lake. Environ Earth Sci 73: 3963-3973.

Kolada A, Soszka H, Cydzik D, Gołub M. 2005. Abiotic typology of Polish lakes. Limnologica 35: 145-150.

Kolada A, Soszka H, Kutyła S, Pasztaleniec A. 2017. The typology of Polish lakes after a decade of its use: a critical review and verification. Limnologica 67: 20-26.

Kondracki J. 2002. Geografia regionalna Polski, Wydawnictwo Naukowe PWN, Warszawa, $441 \mathrm{p}$

Kratzer CR, Brezonik PL. 1981. A Carlson-type trophic state index for nitrogen in Florida lakes. Water Resour Bull 17: 713-715.

Lean D. 1998. Attenuation of solar radiation in humic waters. In: Hessen DO, Tranvik LJ, eds. Aquatic Humic Substances, Ecology and Biogeochemistry, Berlin: Springer, pp. 109-124.

Leenheer JA, Croué JP. 2003. Characterizing aquatic dissolved organic matter. Environ Sci Technol 37: 18-26.

Lenard T. 2009. Metalimnetic bloom of Planktothrix rubescens in relation to environmental conditions. Oceanol Hydrobiol Stud 38: $45-53$.

Lenard T, Ejankowski W. 2017. Natural water brownification as a shift in the phytoplankton community in a deep hard water lake. Hydrobiologia 787: 153-166.

Lürling M, De Senerpont Domis LN. 2013. Predictability of plankton communities in an unpredictable world. Freshw Biol 58: 455-462.

Mathes J, Plambeck G, Schaumburg J. 2002. Das Typisierungssystem für stehende Gewässer in Deutschland mit Wasserflächen ab $0.5 \mathrm{~km}^{2}$ zur Umsetzung der Wasserrahmenrichtlinie. In: Deneke R, Nixdorf B, eds. Implementierung der EU-Wasserrahmenrichtlinie in Deutschland: Ausgewählte Bewertungsmethoden und Defizite, Aktuelle Reihe BTU Cottbus 5/2002, pp. 15-24.

Michalczyk Z, Chmiel S, Turczyński M. 2011. Lake water stage dynamics in the Lęczna-Włodawa Lake District in 1991-2010. Limnol Rev 11: 113-122.

Mischke U, Riedmüller U, Hoehn E, Schönfelder I, Nixdorf B. 2008. Description of the German system for phytoplankton-based assessment of lakes for implementation of the EU Water Framework Directive (WFD). In Mischke U, Nixdorf B, eds. Gewässerreport 10, Aktuelle Reihe 2/2008, University Cottbus, pp. 117-146.

Nicolle A, Hallgren P, von Einem J, Kritzberg ES, Granéli W, Persson A, Brönmark Ch, Hansson L-A. 2012. Predicted warming and browning affect timing and magnitude of plankton phenological events in lakes: a mesocosm study. Freshw Biol 57: 684-695.

Nõges T, Nõges P, Laugaste R. 2003a. Water level as the mediator between climate change and phytoplankton composition in a large shallow temperate lake. Hydrobiologia 506-509: 257-263.

Nõges P, Nõges T, Tuvikene L, Smal H, Ligęza S, Kornijów R, Peczuła W, Bécares E, Garcia-Criado F, Alvarez-Carrera C, Fernández-Alaéz C, Ferriol C, Miracle MR., Vicente E, Romo S, van Donk E, van de Bund W, Jensen J-P, Gross EM, Hansson L-A, Gyllström M, Nykänen M., de Eyto E, Irvine K, Stephen D, Collings SE, Moss B. 2003b. Factors controlling hydrochemical and trophic state variables in 86 shallow lakes in Europe. Hydrobiologia 506-509: 51-58.

Nürnberg GK, Shaw M. 1999. Productivity of clear and humic lakes: nutrients, phytoplankton, bacteria. Hydrobiologia 382: 97-112.

Nush EA. 1980. Comparison of different methods for chlorophyll and phaeopigment determination. Arch Hydrobiol 14: 14-36.

Nygaard G. 1949. Hydrobiological studies on some Danish ponds and lakes II. The quotient hypothesis on some new or little known phytoplankton organisms. Det Kongelige Danske Videnskabernes Selskab 7, $293 \mathrm{p}$.

Ott I, Laugaste R. 1996. Fütoplanktoni koondindeks (FKI), üldistus Eesti järvede kohta. Eesti Keskkonnaministeeriumi infoleht 3: 7-8.

Ott I, Kõiv T, Nõges P, Kisand A, Järvalt A, Kirt E. 2005. General description of partly meromictic hypertrophic Lake Verevi, its ecological status, changes during the past eight decades and restoration problems. In: Ott I, Kõiv T, eds. Lake Verevi, Estonia - a highly stratified hypertrophic lake. Hydrobiologia 547: 1-20.

Pace ML, Cole JJ. 2002. Synchronous variation of dissolved organic carbon and color in lakes. Limnol Oceanogr 47: 333-342.

Pagenkopf, GK, Whitworth, C. 1981. Precipitation of metal-humate complexes. J Inorg Nucl Chem 43: 1219-1222.

Pålsson C, Granéli W. 2004. Nutrient limitation of autotrophic and mixotrophic phytoplankton in a temperate and tropical humic lake gradient. J Plankton Res 26: 1005-1014.

Pasztaleniec A. 2016. Phytoplankton in the ecological status assessment of European lakes - advantages and constraints. Environ Prot Nat Resour 27, 1: 26-36.

Phillips G, Free G, Karottki I, Laplace-Treyture Ch, Maileht K, Mischke U, Ott I., Pasztaleniec A, Portielje R, Søndergaard M, Trodd W, Van Wichelen J. 2014. Water Framework Directive Intercalibration Technical Report, Northern Lake Phytoplankton Ecological Assessment Methods, European Commission, Joint Research Centre, Luxembourg: Publications Office of the European Union, $186 \mathrm{p}$.

Pielou EC. 1966. The measurement of diversity in different types of biological collections. $J$ Theor Biol 13: 131-144.

Schindler DW. 1971. A hypothesis to explain differences and similarities among lakes in the experimental lakes area, Northwestern Ontario. J Fish Res Board Can 28: 295-301.

Sepp M, Kõiv T, Nõges P, Nõges T. 2018. Do organic matter metrics included in lake surveillance monitoring in Europe provide a broad picture of brownification and enrichment with oxygen consuming substances? Sci Total Environ 610-611: 1288-1297.

Sokal RR, Rohlf FJ. 1995. Biometry: The Principles and Practice of Statistics in Biological Research, New York: W.H. Freeman and Company, $887 \mathrm{p}$.

Søndergaard M, Jensen JP, Jeppesen E. 1999. Internal phosphorus loading in shallow Danish lakes. Hydrobiologia 408/409: $154-152$.

Sugier P. 2008. Characteristics of Lake Rogóźno macrophytes and their role in preservation of biodiversity. TEKA Commission of Protection and Formation of Natural Environment the Lublin Branch of PAN 5: 138-144.

Szyper H, Gołdyn R. 2002. Role of catchment area in the transport of nutrients to lakes in the Wielkopolska National Park in Poland. Lakes Reservoirs Res Manage 7: 25-33.

Utermöhl H. 1958. Zur Vervolkommnung der quantitativen Planktonmethodik. Mitteilung. Int Vereinigung Theor Amgew Limnol 9: $1-38$.

Vasiljev J. 1998. The simulated response of lakes to changes in annual and seasonal precipitation: implication for Holocene lake-level changes in northern Europe. Clim Dyn 14: 791-801.

Weyhenmeyer GA, Müller RA, Norman M, Tranvik TJ. 2016. Sensitivity of freshwaters to browning in response to future climate change. Clim Change 134: 225-239.

Yong STY, Chen W. 2002. Modelling the relationship between land use and surface water quality. J Environ Manage 66: 377-393.

Cite this article as: Lenard T, Ejankowski W, Poniewozik M. 2018. Does an increase in water color intensity affect the lake trophic status and phytoplankton metrics? Knowl. Manag. Aquat. Ecosyst., 419, 46. 